Federal Reserve Bank of San Francisco Stanford Institute for Economic Policy Research

\title{
Interest Rates and Monetary Policy
}

Federal Reserve Bank of San Francisco, Fourth Floor

March 19 - 20, 2004

\section{AGENDA}

\section{Friday, March 19}

Morning Session Chair: John Williams, Federal Reserve Bank of San Francisco

8:15 A.M. Continental Breakfast

8:55 A.M. Welcoming Remarks:

Robert Parry, Federal Reserve Bank of San Francisco

9:00 A.M. Monika Piazzesi, University of Chicago

Eric Swanson, Federal Reserve Board

Future Prices as Risk-Adjusted Forecasts of Monetary Policy

Discussants: Charles Evans, Federal Reserve Bank of Chicago Frank Schorfheide, University of Pennsylvania

10:30 A.M. Break

11:00 A.M. Glenn Rudebusch, Federal Reserve Bank of San Francisco Tao Wu, Federal Reserve Bank of San Francisco A Macro-Finance Model of the Term Structure, Monetary Policy, and the Economy

Discussants: Greg Duffee, University of California, Berkeley Bennett McCallum, Carnegie Mellon University

12:30 P.M. Lunch - Market Street Dining Room, Fourth Floor

Afternoon Session Chair: Richard Dennis, Federal Reserve Bank of San Francisco

2:00 P.M. Andrew Ang, Columbia University Geert Bekaert, Columbia University The Term Structure of Real Rates and Expected Inflation

Discussants: Martin Evans, Georgetown University Ken West, University of Wisconsin 
3:30 P.M. Break

4:00 P.M. Sharon Kozicki, Federal Reserve Bank of Kansas City

Peter Tinsley, George Washington University

Permanent and Transitory Policy Shocks in an Empirical Macro Model

with Asymmetric Information

Discussants: Alan Blinder, Princeton University

Steven Durlauf, University of Wisconsin

5:30 P.M. Reception - West Market Street Lounge, Fourth Floor

6:30 P.M. Dinner - Market Street Dining Room, Fourth Floor

Introduction: Robert Parry, Federal Reserve Bank of San Francisco

Speaker: $\quad$ Ben Bernanke, Federal Reserve Board

\section{Saturday, March 20}

Morning Session Chair: Narayana Kocherlakota, Stanford University

8:00 A.M. Continental Breakfast

8:45 A.M. Qiang Dai, New York University

Kenneth J. Singleton, Stanford University

Wei Yang, Stanford University

Regime Shifts in a Dynamic Term Structure Model of U.S. Treasury

Bond Yields

Discussants: James Hamilton, University of California, San Diego

John Heaton, University of Chicago

10:15 A.M. Break

10:30 A.M. Alexei Onatski, Columbia University

Noah Williams, Princeton University

Empirical and Policy Performance of a Forward-Looking Monetary Model

Discussants: Jeffrey Fuhrer, Federal Reserve Bank of Boston

Lars Hansen, University of Chicago

12:00 P.M. Lunch 